\title{
BUILDING CONTROL AND REGULATORY BALANCE: PERSPECTIVES OF BUILDING PROFESSIONALS
}

\author{
JEFF CLEMENT SAMASONI and JAMES OLABODE BAMIDELE ROTIMI \\ Construction Management Programme, School of Engineering, Computer and Mathematical \\ Sciences, Auckland University of Technology, Auckland, New Zealand
}

\begin{abstract}
The New Zealand government proposed a new control regime to streamline the process of building approval by introducing risk-based inspections for certain types of building works. With this regulatory balance could be proportioned to stakeholders involved in the building process. A review of the Building Act in 2010 had indicated that a more balanced approach to building control is required to more appropriately allocate responsibility, accountability and liability between construction stakeholders. A larger study on which the current study is based, evaluates stakeholders perception of the newly introduced risk-based building inspection scheme and on regulatory balance issues. Building inspectors expressed concern in the shift in balance, as current regulatory inspections had a high proportion rate of failures involving competent building practitioners. However the scheme provides building regulators a tool to accelerate building processes without compromising cost and quality.
\end{abstract}

Keywords: Building regulations, Government, Housing, Liability, Risk, Inspections.

\section{INTRODUCTION}

In August 2009 the New Zealand government announced a review of the Building Act 2004 and identified issues that there were problems with ensuring responsibility sat in the right place and undue reliance on building consent authorities (BCA) (Williamson 2010a). The building consent authority post the leaky home saga in the late 1990s have been risk-averse with the consenting process requiring more documentation and checks and the addition of more inspections which has been applied to every project that is lodged with council. An example of this process would be a housing developer firm providing the same documentation on it stock standard house design which has been through the BCA numerous time but still require further information depending on which BCA officer was processing or inspecting it (May and Wood 2003). The added pressures of the Auckland house shortages (Auckland Council 2013) and the Christchurch rebuild (MBIE 2013) has forced the government to take action. The government's announcement particular targets BCA in relinquishing its control and oversight of building work and proportionally moving risk to other professional e.g., architects, engineers and licensed building practitioners who are in the best position to assess it. The rebalancing of the building consent process will be a major change in liability shift as BCA input into certain projects would be dramatically reduced and professionals picking up the shortfall.

The government focus on achieving quality homes, through building activities that is business-enabling and within an efficient regulatory framework. In other words, construction 
productivity that is conducted by competent personal which is value for money while being streamline through a user friendly business model. It also targeted consumers' confidence that they are able to make informed decisions in carrying out transactions in the building and housing market (DBH 2009).

A report by the Building and Construction Sector Productivity Taskforce (DBH 2009) also supports these findings in that productivity within the construction industry is relatively lower than those in other sectors of the New Zealand economy and part of its recommendation was developing quicker regulatory and consenting processes to reduce the barriers and roadblocks that urban development's face.

\section{LITERATURE REVIEW}

\subsection{Ensuring Responsibility Sit in the Right Place}

It is a well-known fact in New Zealand that responsibility and accountability for ensuring building quality and reducing the number of defects is not well aligned to the ability of each key construction stakeholder to effectively make an impact. The lessons from the leaky home saga in which the government and homeowner were usually "the last man standing" in picking up the repair bill indicated that responsibility and accountability were not fairly distributed to those best to manage risk. The government financial aid package (FAP) for leaky home owners is an example of the distribution of liability through repair funds where $25 \%$ is summoned to central government, $25 \%$ from local government (Subject to that they signed the final compliance certificate) and $50 \%$ by the owner. It is evident through this process that other key stake holders (designers, builders and product manufactures) are not part of this claim as many are known to shut down their business which have been subject to a claim and restart a new one which is a major problem in the New Zealand construction industry.

The roles of the different stakeholder and building consent authorities are not always clearly defined or understood (Massey 1999). The current regime there is strong expectation on the role of building consent authorities in reviewing and inspecting consented plans to protect consumers from defective building work, even when the risk and consequences of failure are low (May and Burby 1998). This has reverted councils into a risk-averse approach because the "duty of care" Invercargill City Council v Hamlin ${ }^{1}$, imposed by the courts on local authorities in respect of residential homeowners because of their statutory responsibility to issue building consent, carry out inspections and issue code compliance certificates. Many stakeholders which had been implicated in negligence cases relating to leaky buildings (May 2003) avoided payment of the proportion of damages due to creating limited-life companies. As a result of these parties unable to contribute to their part of the cost these were deferred to those who could which were the local authority and their rate payers. The government review in 2009 emphasis that dependence on building consent authorities is out of balance with their ability to influence building quality through documentation and inspection, and their capacity to do so without considerable cost. It has the consequences of imposing higher than necessary costs. Themes that were constant through the review were excessive requests by building consent authorities for documentation and plans which contributed to slow processing of consents. A large number of inspections during the course of construction, excessive in the case of simple buildings and a reluctance by building

\footnotetext{
${ }^{1}$ is a cited case in New Zealand regarding council liability for negligent inspection, as well the issue in tort when the start period for the statute of limitations for a latent defect begins
} 
consent authorities to approve new or alternative building designs, products or processes (DBH 2009).

\subsection{Moving to a More Balanced Approach to Building Control}

Another of the government's objectives of the proposal would see BCA targeting their oversight at buildings and building work where the risks and consequences of failure are most significant. Some of the options are:

- Building professionals, trades people and owner-builders would be able to undertake more of the lowest-risk work without needing building consents.

- A more streamlined process for low-risk (simple residential) buildings when the work is undertaken or overseen by licensed building practitioners.

- In the commercial sector, a more streamlined process for complex commercial building work that acknowledges the commercial risk-management and quality-assurance processes already in use.

- Importantly, retaining the current building consent system for more complex and less conventional residential building, and some commercial buildings, because of the higher risk and greater consequences of failure (Williamson 2010b).

\subsection{Risk-based inspection}

There is no single accepted or correct definition of risk. Rothstein et al. (2006) perceives riskbased regulation as allocating resources in proportion to risks to society (such as health, safety or environmental risks), in which the consequences of it happening and the overall impact are considered, in order to establish appropriate levels of control. Imrie and Street (2009) elude to the development of building controls as an example of the modernist conception of risk, whereby state directives set out minimum standards of building performance, based on a series of written rules.

Current regulations are increasingly seen as barriers to market liberalization and as a result there is an international trend towards reducing government responsibility for building quality and many countries are attempting to simplify their building control regimes, often through a combination of deregulation and the shifting of responsibility and in some cases balance to the private sector (Yau 2009). This is such the case where one large regulator the environmental agency for England and Wales, has responded to such pressures by implementing risk-based approaches to regulations (Gouldson et al. 2009).

Risked based inspections is an established practice in a number of areas of United Kingdom health, safety and environmental enforcement, with examples found in the enforcement of food safety, Hobbs et al. (2002) fire safety, Ramachandran (1999), and occupational health and safety, Tombs and Whyte (2013), In each case the frequency of inspection and associated enforcement actions are based on a combination of the risk posed by the activity and the standard of management.

The Department of Communities and local government (DCLG) in the UK has also introduced a risk-based inspection tool to their building control departments (DCLG 2012a). The risk-based inspection systems include a minimum number of phased inspections for all buildings, they typically give priority to buildings with high risk, such as environmental ones and optimize the process. Having fewer inspections for less risky buildings lowers costs without compromising 
safety, increasing flexibility and enabling inspectors to move away from random and phased inspections (DCLG 2012b).

Risked based inspections in New Zealand will be in the form of allocating inspections to those building projects that are at a high risk of failure and reducing or exempting inspection for those with lower risk of failure.

\section{THE RESEARCH}

\subsection{The Research Objectives}

The literature review has provided some background analysis into the movement of balance between key stakeholders in the building controls process in New Zealand, and looks at those key professional parties that will be affected. It also explores the concept of implementing a process where those who design and construct buildings and building work will need to stand by their work with the reduced over sight of regulatory checks therefore taking on more responsibility and accountability if anything should go wrong.

The introduction of risk-based inspection also provided building consent authorities a tool to focus their resources on the more complex projects and eliminate the need for simple building designs and those of low risk failures. The review concluded that there is a need to examine the reduction of regulatory involvement into the building consent process and the utilization of riskbased inspection (Williamson 2010) as a BCA tool in New Zealand. Thus the following research objectives are suggested which are also in line with the government recommendations:

(1) To promote a regulatory system that is administered in an efficient and cost effective manner

(2) To ascertain problems with ensuring responsibility sits in the right place

(3) To establish an undue reliance on building consent authorities

\subsection{Research Methodology}

This study is undertaken to provide an understanding of proposed changes to the building consent process in New Zealand and its effects with its key stakeholders.

The main form of data collection was in the form of semi-structured survey which went out to building designers and building control practitioners in New Zealand. Deliberate sampling was targeted at areas which had the largest volume of work through their Building Consent Authorities throughout New Zealand (Auckland, Hamilton, Wellington and Christchurch) for this not only covered the majority of the population but also covered the geographic makeup of the country. Building designer were also deliberate targeted which were members of the New Zealand Institute of Architects (NZIA) as majority of their members were registered architects. Interviewee diversification is essential to the quality of data sourced in quantitative and qualitative research, therefore all participants that had be engaged for the research will have practical understanding of the building consent process and be competent in their field of professionalism. All surveyed questionnaires responses are analysed through SPSS and open ended question through the NVivo program.

\section{FINDINGS}

Table 1 presents results from building professionals in which survey question asked "Does there need to be a review on the current number of inspection for a new residential dwelling". The 
findings in table 1 indicate that building professionals $(70.25 \%)$ overwhelming agree that the current regulatory inspection required less regulatory intervention which aligns to the UK Department of Communities and local government initial intention for regulatory change to their building controls scheme for reduced inspections.

Table 1. Building professional's perspective on review of current regulatory building inspections.

\begin{tabular}{lccc}
\hline Responses & Percentage \% & Count & Total \\
\hline Yes & 70.25 & 88 & \\
No & 18.85 & 22 & \\
Not sure & 10.9 & 16 & \\
& & & 126 \\
\hline
\end{tabular}

Table 2 presents results from building professionals in which survey question asked "Is the New Zealand construction industry ready for current regulatory inspections to be relaxed in favour of a risk-based assessment approach". The findings in table 2 indicate that nearly $60 \%$ of building professionals do not think that the relaxation of regulatory inspections in favour of a risk-based assessment approach is a positive move as more stringent regulatory governance of construction stakeholders need to be in place before responsibility is shifted.

Table 2. Building professional's perspective on a risk-based assessment approach.

\begin{tabular}{lccc}
\hline Responses & Percentage \% & Count & Total \\
\hline Yes & 24.5 & 34 & \\
No & 58.85 & 72 & \\
Not sure & 16.7 & 20 & \\
& & & 126 \\
\hline
\end{tabular}

\section{CONCLUSION}

The research seeks a better understanding of the perceptions of building professionals towards regulatory balance and the implementation of risk-based inspection as a building consent authority tool. The stigma of the leaky home is still evident in the post consenting processes of building control authorities in New Zealand and the intentions of the 2004 building act were warranted but in the same token has refrained innovation and productivity. The government and construction working group through the Building Amendment Act 2010 and 2012 has recognized these bottlenecks and have proposed new objectives to get the construction industry producing to its full potential. The findings show that a majority of building professionals in New Zealand agree that there are too many regulatory inspection notification in the current system. This affirms the fact that post the leaky building crisis that building consent authorities have been over zealous in confirming regulatory compliance during consenting and construction phases.

Majority of building professionals also disagreed that the relaxation of regulatory inspections in favor of risk-based inspections is a good idea. Further commentary suggest that New Zealand construction industry is not mature enough and until the government regulated an insurance bond for licensing building practitioners who produce non-substantial work a repeat of the leaky home saga would be imminent. The conclusion of the programme study suggests that the current building regulatory inspection regime definitely requires a review but more education and understanding of risk-based inspection to all key stakeholders is needed if this is to be used as a building control authority tool. 


\section{References}

Auckland Council, The Auckland Plan 2013, Housing actions plan. New Zealand, 2013.

Department of Building and Housing (DBH). Report of the Building and Sector Productivity Taskforce, New Zealand, 2009.

Department for Communities and Local Government (DCLGa). Proposed changes to the building control system: Consultation stage impact assessment. Department for Communities and Local Government. London, 2012.

Department of Communities and local government (DCLGb). Risk assessment decision making tool for building control bodies. Department for Communities and Local Government. London. 2012.

Gouldson, A., Morton, A. and Pollard, S. J. T. Better environmental regulation - contributions from riskbased decision-making. Science of the Total Environment 407(19): 5283-5288, 2009.

Hobbs, J., Fearne, A., and Spriggs, J. Incentive Structures for Food Safety and Quality Assurance: An International Comparison. Food Control, 13(2): 77-81. http://doi.org/10.1016/S0956-7135(01)00103-7, 2002.

Imrie, R. and Street, E. Risk, regulation and the practices of Architects. Urban Studies 46(12): 2555-2576. http://doi.org/10.1177/0042098009344231, 2009.

Invercargill City Council v Hamlin [1994] 3 NZLR 513, [1996] 1 NZLR 513 (1994).

Massey, W. Guide to the Building Act. New Zealand, 1999.

May, P. J. Performance-based regulation and regulatory regimes: The saga of leaky buildings. Law \& Policy 25(4): 381-401, 2003.

May, P. J. and Burby, R. J. Making sense out of regulatory enforcement. Law and Policy 20(2), 1998

May, P. J. and Wood, R. S. At the regulatory front lines: Inspector's enforcement styles and regulatory compliance. Journal of Public Administration Research and Theory 13: 117-139, 2003.

Ministry of Business, Innovation \& Employment (MBIE). Housing pressures in Christchurch: A summary of the evidence 2013. Wellington, New Zealand, 2013.

Ramachandran, G. Fire safety management and risk assessment. Facilities 17(9/10): 363-376, 1999.

Rothstein, H., Irving, P., Walden, T. and Yearsley, R. The risks of risk-based regulations: Insights from the environmental policy domain. Elsevier, 2006.

Tombs, S. and Whyte, D. Transcending the deregulation debate? Regulation, risk, and the enforcement of health and safety law in the UK, (July 2012): 61-79. http://doi.org/10.1111/j.1748-5991.2012.01164.x, 2013

Williamson, M. Building Act Review 5: Delivering Building regulation. Office of the Minister of Building and Construction. New Zealand, 2010a.

Williamson, M. Building Act Review 3: Stepped Consenting. Office of the Minister of Building and Construction. New Zealand, 2010b.

Yau, Y. On the proposed private certification of building works in Hong Kong. International Journal of Law in the Built Environment 1(3): 221-233, 2009. 